Journal of Southeast Asian

2015

\title{
Lessons Learned: Insights into One Teacher's Experience Working with Karen Refugee Students in the United States
}

Daniel J. Gilhooly

The University of Georgia, danjgilhooly@gmail.com

Follow this and additional works at: https://docs.lib.purdue.edu/jsaaea

Part of the Applied Linguistics Commons, Asian Studies Commons, First and Second Language Acquisition Commons, Junior High, Intermediate, Middle School Education and Teaching Commons, and the Secondary Education and Teaching Commons

\section{Recommended Citation}

Gilhooly, Daniel J. (2015) "Lessons Learned: Insights into One Teacher's Experience Working with Karen Refugee Students in the United States," Journal of Southeast Asian American Education and Advancement. Vol. 10 : Iss. 1, Article 2.

DOI: $10.7771 / 2153-8999.1121$

Available at: https://docs.lib.purdue.edu/jsaaea/vol10/iss1/2

This document has been made available through Purdue e-Pubs, a service of the Purdue University Libraries. Please contact epubs@purdue.edu for additional information.

This is an Open Access journal. This means that it uses a funding model that does not charge readers or their institutions for access. Readers may freely read, download, copy, distribute, print, search, or link to the full texts of articles. This journal is covered under the CC BY-NC-ND license. 


\title{
JSAAEA Journal of Southeast Asian American
Education and Advancement
}

Volume $10(2015)$

Www.JSAAEA.org

\section{Lessons Learned: Insights into One Teacher's Experience Working with Karen Refugee Students in the United States}

\author{
Daniel Gilhooly \\ University of Georgia
}

\begin{abstract}
This study is informed by funds of knowledge and culturally responsive teaching studies that aim to explore and legitimize the cultural knowledge immigrant children bring to their communities and schools. Consequently, this paper specifically addresses issues related to the educational experiences of Karen children and their parents from one American teacher/researcher who has worked with the Karen for the past four years. In aggregate, this paper addresses issues germane to Karen education including; (1) background information on Karen educational experiences prior to resettlement, including a review of their journey from Thailand to the U.S.; (2) important characteristics of Karen culture; (3) Karen names; (4) Sgaw Karen language characteristics; (5) the language divide between parents and children; (6) parental involvement in their children's schooling; (7) American teacher perceptions of Karen students; (8) issues over grading and, finally; (9) gender issues.
\end{abstract}

KEYWORDS: Refugee education; ESL; Sgaw Karen; funds of knowledge; culturally responsive teaching

I want people to know that I am not Mexican and I am not Chinese or Burma people! I was born Thailand but I am Karen! Why it is so difficult? (Julie Htoo (pseudonym), age 13, 2013, Georgia)

This excerpt from an exacerbated Karen girl was one of the motivations behind this paper. Her frustrations and pride in her Karen identity speak to the experiences of many immigrant children who face similar challenges of living in the bifurcated worlds of home and school. Moreover, it speaks to the ambivalence of many Americans toward Asians in their neighborhoods and

\footnotetext{
@)

SOMERIGHISRESERVEDReaders are free to copy, display, and distribute this article, as long as the work is attributed to the author(s) and the Journal of Southeast Asian American Education \& Advancement, it is distributed for non-commercial purposes only, and no alteration or transformation is made in the work. More details of this Creative Commons license are available at http://creativecommons.org/licenses/by-nc-nd/3.0/. All other uses must be approved by the author(s) or JSAAEA.
}

Journal of Southeast Asian American Education \& Advancement, Vol. 10 (2015) ISSN: 2153-8999 
Gilhooly - Lessons Learned

classrooms. The following pages represent my story and the lessons learned from teaching and assisting a Sgaw Karen community in rural Georgia, USA.

\section{Background}

From May 2010 to June 2014, I worked as a language tutor in a nearby rural Karen community while pursuing my doctoral degree in Teaching English as a Second Language (TESOL) at a large public university. This particular paper is also informed by a larger qualitative study on Karen resettlement. In 2011, I conducted a participatory action research (PAR) project alongside three Karen brothers who were my students in the small rural community of Sandville (pseudonym), Georgia.

That PAR study looked at a wide variety of issues related to Karen resettlement in four different Karen communities, two in the Midwest and two in the southeastern part of the United States where we conducted interviews, distributed questionnaires, and video recorded our research experiences. That study and an earlier research project based on my participant observations on the schooling experiences of those three Karen brothers, both received Institutional Review Board (IRB) approval and are the primary sources of data for this paper. The primary research questions that guided this paper are:

(1) What important cultural and historical considerations can help inform those working with the Karen?

(2) What are the primary issues and concerns of Karen students, parents and their teachers as Karen families navigate the U.S education system?

(3) How might teachers integrate Karen students' funds of knowledge into their classrooms?

\section{Theoretical Framework}

This paper intends to follow in the tradition of the ethnographic work of teachers/researchers like Donald Hones. Like Hones (2002), I believe that teachers can be more effective in addressing immigrant students if they become knowledgeable about their cultural, historical, and linguistic backgrounds.

Like Hones, I contend that teachers need to apprise themselves of the unique cultural and historical backgrounds of their students. Therefore, I first draw on culturally responsive teaching as presented by Geneva Gay $(2010,2002)$. According to Gay (2010), teachers need to become aware of their students' cultures and lived experiences in order to address their needs as well as to legitimize their cultural heritage. More importantly, as Gay contends, such awareness can improve instruction for those children who are currently falling through the educational cracks. For transnational students like the Karen, I believe it is important that teachers become aware of students' immigration (transnational, diasporic, immigration and secondary migration) experiences so as to better address their emotional, psychological, social, and academic needs.

This paper is also informed by funds of knowledge as presented by Norma Gonzalez and Luis Moll (1993, 1995, 2005). According to Moll et al. (1992), funds of knowledge refers to the "knowledge and skills found in local households" (p. 132). The goal is for teachers to recognize their students' diverse home cultures in order to integrate the students' home knowledge and skills into their classroom teaching. I specifically address ways teachers can utilize students various funds of knowledge in the final implications section of this paper.

Both culturally responsive teaching and funds of knowledge offer an alternative to the deficit model (Gonzalez \& Moll, 1993) or cultural deprivation paradigm (Gay, 2010) that often 
Gilhooly - Lessons Learned

view immigrant children as inherently lacking in cultural/social capital and the skills needed to succeed academically and socially in the classroom. Rather, both funds of knowledge and culturally responsive teaching consider the many ways students bring valuable cultural, linguistic, and social practices with them into their American classes. Towards this aim, I present a brief background of the Burmese students entering American classrooms.

\section{Burmese Refugees}

The Karen (pronounced kuh-REN, sometimes referred to as Kayin) people and their resettlement to the U.S. has garnered little public attention over the seven years since they began resettling to the U.S. Therefore, I have elected to provide a short history of the people and offer a description of their journey from Burma to Thailand and, ultimately, to the United States. Firstly, some clarification is warranted regarding who is resettling from the refugee camps along the ThaiBurma border.

Although refugees originating from Burma ${ }^{1}$ are designated as Burmese by the U.S. government, the designation Burmese ${ }^{2}$ is somewhat misleading. In fact, the United States has been resettling multiple ethnic groups under the designation Burmese: Burman (3.81\%), Chin (33\%), Karenni (8\%), and the largest group, Karen (47\%) (Refugee Processing Center, 2014). Moreover, the Karen are not a homogenous ethnic group; they consist of multiple language groups; namely Sgaw, Pwo, and Bwe. This study looks at the largest Karen sub-group coming to the United States, Sgaw (also spelled Sgau or Skaw) Karen. Importantly, much of the confusion surrounding the ethnicity of students arriving from Burma originates in the children. For instance, in all my interactions with Karen in the U.S., respondents invariably answered "Thailand" when asked, "Where are you from?" This response often leads teachers and those working with the community to misidentify these students as Thai.

\section{The Karen: From Missionaries to Main Street}

The people known as Karen come from various regions throughout Burma and the eastern hills of Thailand. Most originate in the Karen state, which lies on Burma's eastern border with central Thailand. Historical animosity between Karen and Burman ${ }^{3}$ intensified with the near simultaneous arrival of American missionaries and the British colonial enterprises in the early nineteenth century (Harriden, 2002; Smith, 1999; Thawnghmung, 2008).

The Karen people remain relatively anonymous in the United States despite a vast amount of anthropological and ethnographic literature dedicated to them and their current presence in all 50 U.S states. Surprisingly, despite this anonymity the Karen have a long history with Americans as Adoniram and Anne Judson established the first American mission abroad in Burma in $1813^{4}$. The Karen represent the Judson's and later missionaries' greatest success. Many Karen supported the American missionaries and the British colonial enterprise. Karen served in the colonial police, civil service, and military forces under the British (Thawnghmung, 2012). These alliances played a critical role in the development of Karen culture, education, identity, nationalism, and religion over the ensuing 200 years (Cusano, 2001; DeLang, 2000; Harriden, 2002).

The role of Christianity on Sgaw Karen culture, history, and language cannot be underestimated. Karen conversion to Christianity introduced not only religion but provided the Karen access to Western education, medicine, and protection from their historical adversaries, the Burmans. Today, between $20 \%$ and $30 \%$ of Karen are Christian and most resettling to the U.S. are either Baptist or Seventh Day Adventist. ${ }^{5}$

Journal of Southeast Asian American Education \& Advancement, Vol. 10 (2015) 
Gilhooly - Lessons Learned

After independence from the British in 1948, many Karen political organizations competed for representation of all Karen people (Falla, 1991; Thawnghmung, 2008). This division led to disparate goals regarding a path forward post-independence. One route was an armed insurgency instituted by various paramilitary organizations. The Karen National Union (KNU), the largest Karen political group, has continually called for an independent Karen state and their military wing, the Karen National Liberation Army (KNLA), has fought subsequent Burmese governments using guerilla style tactics for over six decades. This insurgency and its suppression by the Burmese military has led to the displacement of hundreds of thousands of Karen and other ethnic minorities.

Ethnic minorities, including the Karen, have faced persecution in the form of forced labor, rape as a weapon of war, forced conscriptions into the military ${ }^{6}$, burning and looting of villages, mass killings, and forced relocation of villages (Malseed, 2008; Milbrandt, 2012; TBBC, 2008). The civil war has led to both internal and external displacement. The Karen students arriving in U.S. classrooms are part of this diaspora.

Drawing on Bauböck and Faist (2010), I view diaspora as having three distinct characteristics. The first relates to the "forced dispersal" of a particular group. Second, the term relates to the "cross-border experiences of homeland and destination" (p. 13). Third, diaspora relates to the integration of these groups into the countries of settlement. The Karen fulfill each of these characteristics. First, most Karen fled Burma because of persecution or the threat of persecution but were able to maintain varying degrees of connection with family and co-ethnics in Burma. In the U.S., many Karen are able to maintain ties with family and friends in the camps as well as back in Burma. Finally, many Karen have been able to integrate into Thai society with varying degrees of success and are currently transitioning into life in the U.S. and other third country host nations.

\section{Resettlement to the USA}

The United States government began resettling Burmese, namely Karen, refugees in earnest in 2006. To date, an estimated 50,000 Karen have been resettled in states across the U.S. with the majority settling in Minnesota, New York, Texas and California (Refugee Processing Center, 2014). Although registration for group resettlement ended in January 2014, Karen and other Burmese refugees are expected to continue resettling into 2015.

\section{Methods}

This longitudinal ethnography is informed primarily by my ongoing participant observation as a tutor in the Sandville (pseudonym) community in rural Georgia from 2010 to June 2014. Qualitative methods such as field notes, interviews, and multiple informal conversations with teachers, students, neighbors (American neighbors of Karen families), and Karen parents were the primary data sources. In addition, this study is formed by the corpus of studies I have read on Karen culture, history, religion, Diaspora, and resettlement to the United States and Australia. This study focuses on those findings related to the students' overall education experiences.

\section{Participants}

In May of 2010 I was initially hired by the Georgia Migrant Consortium, a branch of the state's Department of Education, to tutor twelve Karen students (see Table 1.1) from four families at their homes for 12 weeks, 16 hours per week. At the end of the summer I continued to tutor/research three of the original four families over the next three years, with periodical 
Gilhooly - Lessons Learned

funding, until June, 2014. However, regardless of funding I worked with the children consistently (minimum of once a week for 4 hours) over the four-year period. Over time I worked with other children visiting the area and in 2012 a fifth family became a part of my weekly tutoring routine (see Table 1.1). My teaching primarily focused on age and level appropriate English activities, helping with homework, preparing for state and national exams, and much informal conversation.

Table 1.1

Student Demographics of Five Families upon First Meeting, May 2010

\begin{tabular}{llll}
\hline Family & Student & Age & Grade \\
\hline Family One & Male & 19 & 11 \\
& Male & 17 & 11 \\
& Male & 14 & 9 \\
& Male & 10 & 4 \\
\hline Family Two & Female & 9 & 1 \\
(Cousins of & & & \\
Family One) & & 15 & 9 \\
\hline Family Three & Male & 12 & 5 \\
& Male & 9 & 3 \\
& Male & 7 & $\mathrm{~K}$ \\
& Female & 5 & Pre-K \\
& Male & 7 & 1 \\
\hline Family Four* & Female & 5 & Pre-K \\
(Cousins of & Male & & 7 \\
Family One) & & 12 & 4 \\
\hline Family Five** & Female & 9 & $\mathrm{~K}$ \\
& Female & 6 & \\
\hline
\end{tabular}

Note.* I only taught the two children in Family Four during the summers of 2010 and 2012. I stopped teaching them because they were both excelling in school and moved three miles from other families.

** I began teaching Family Five in 2012 and worked with them continuously to June, 2014.

Although the families resettled to the U.S. separately, each family resettled in 2007 or early 2008. Therefore, each of the children (excluding the two pre-k boys) had been attending school in the U.S. between two and three years before working with me. Their English language ability varied greatly. As expected, the younger children demonstrated strong native-like pronunciation in English compared to their older siblings. They also demonstrated more awareness of American idiomatic expressions and were much more language confident than the older students. However, the younger children had less proficiency in spoken Karen and no Karen reading or writing skills. Two boys who resettled at ages 10 and 12 struggled with reading, speaking, and writing English and demonstrated very low language confidence and willingness to communicate.

Similarly, the four adolescent students demonstrated the lowest English language speaking proficiency and were reluctant to speak in English. Therefore, most of our time together was spent helping improve their English, while also helping them prepare for the state's mandatory graduation tests. In October 2011, I received institutional review board approval 
Gilhooly - Lessons Learned

(IRB) for a pilot study that focused on these children's educational experiences from the perspective of my role as teacher/researcher.

At the time of our first meeting I was 39 years old and a doctoral student in a Language and Literacy Department program at a large public university. I had taught English to students of other languages for twelve years before returning to pursue a Ph.D. Significantly, I had also experienced a transnational "uprooting" when my parents decided to move abroad when I was 13 years old. I lived abroad for over four years and believe that my own transnational experiences influenced my sense of compassion and concern for these children, especially those who resettled during adolescence.

\section{Data Collection}

Data collection consisted of four years of participant observation. Field notes, photographs, video recordings, and both structured and unstructured interviews were used during these observations. As a participant observer I was able to observe the children primarily as their tutor. However, throughout the study I varied my routine in order to better capture a more complete and nuanced picture of their lived experiences (Glesne, 2011). I would often vary our teaching schedule, and over the duration of the study we met at different times, on different days, and in different capacities. This variance in meeting times and places was coupled with a variety of different contexts from which I could observe the students. Observing them at the homes of friends and neighbors, the library, church, sports functions, the mall, restaurants, museums, summer camps, weddings, graduations, and at regional and national Karen festivals afforded me a more complete picture of each of the children.

I most often worked with students in small groups or one-on-one in their homes for one or two hours two times each week for, on average, 45 weeks each year. In total, I visited the community as a tutor over 350 times and became well known throughout the community as Thera Dan (Teacher Dan).

\section{Artifacts}

Over the duration of my work with the Karen I have been able to collect a variety of artifacts such as schoolwork, report cards, teacher and school notifications, as well as artwork and other written, photographic, and digital music and video creations. In aggregate, I collected over 87 hours of video recordings of my tutoring sessions, interviews with the children and their parents, Karen festivals, weddings, and sports competitions. In addition, I collected over 1,000 photographs taken by the children of their family, friends, and Karen functions.

\section{Interviews}

Over the four years I have formally interviewed students, their parents, teachers working with Karen, American neighbors, and American friends of the children (see Appendix for sample interview questions for each group). On average, formal interviews lasted between 45 minutes and one hour. I conducted formal interviews with my four adolescent students five times over the four years, and had multiple informal conversations with them. Other times I was able to conduct semistructured group interviews with the children and one or both their parents. All formal interviews were video and audio recorded and then transcribed. Most of the informal conversations were video and/or audio recorded and also transcribed. In aggregate, I conducted structured interviews with three sets of parents three times over the duration of my work. 
Gilhooly - Lessons Learned

Parental consent was attained before all interviews with younger children (under age 18). These forms were written in both English and Sgaw Karen to ensure participant understanding.

Unstructured or informal interviews varied between families based on availability but multiple impromptu interviews were recorded periodically. Finally, over time I was able to interview teachers working with the Karen as well as school friends and neighbors. These relationships snowballed and I began correspondences with other tutors and teachers working with the Karen in other cities and states. In total, I conducted one structured interview with five teachers ( 5 interviews in total) and one tutor as well as single semi-structured interviews with four neighbors and two friends of my adolescent students.

\section{Field Notes}

After each lesson I wrote two separate field notes. One set of notes reflected the day's activities and the students' overall work on assignments and activities. These notes reflected my observations pertaining to individual student's progress. Another set of field notes related to my overall impressions of the visit.

This second set of notes documented my overall impressions regarding the children and their families. I often made notes based on observations of unique Karen cultural characteristics or practices. These notes also documented concerns expressed by parents and students in relation to school, health, mail, and other issues germane to resettlement. Both sets of notes were made into Microsoft Word files using Dragon 10.0 voice recognition software (I often read my handwritten notes and they were converted into Microsoft Word documents) or directly transcribed into Microsoft Word files. These notes were then placed in chronological order in separate folders. These folders were printed and kept in binders for analysis. Finally, I also kept separate folders for each student. These folders consisted of assignments, artwork, awards, teacher notices, and all school records.

\section{Data Analysis}

I used grounded theory as my data analysis tool. In total, I analyzed field notes, interviews, and informal conversations that were video and audio recorded with Karen adolescents, adults, and American teachers. Grounded theory takes the approach that a researcher generates a theory by interacting with the collected data and highlighting emerging themes and patterns from the data (Charmaz, 2006). The grounded theoretical approach is particularly useful when well-established theories of the research topic are not available and will allow the researcher to be informed by the data (Corbin \& Strauss, 2008). The grounded theoretical process began with lower level coding and concluded with higher level theorizing (Charmaz, 2006). Thematic analysis through the constant comparison as well as open coding, categorizing, memo writing were used in order to identify key themes and patterns from the collected data (Corbin \& Strauss, 2008). As a result, I developed conceptual clustered matrices to organize themes (categories), codes, and supporting excerpts. This paper draws specifically on those themes related to Karen educational experiences.

I reviewed all interview transcriptions and field notes and began coding based on those themes related to the students' education experiences. For example, the children talked at length about their teachers in the camps and at school in the U.S. I looked through all transcript incidences of such comments and coded IT (Impression of Teachers) in the margins. Other themes related to students' impressions of teachers would then be added. For example, when 
Gilhooly - Lessons Learned

students spoke about corporal punishment (CP) a new theme emerged and was coded accordingly under the broader heading (IT).

Certain protocols were followed to substantiate my interpretations, choices of representation, and claims. These procedures evolved over time, as I became a more sophisticated researcher. Following Richardson (2000), I have opted for the metaphor of crystallization rather than the more commonly used term triangulation to describe the procedures I used to better understand or validate the multiple perspectives under consideration in this study. Richardson (2000) writes of crystallization:

I propose that the central image for "validity" for postmodern texts is not the triangle-a, rigid, fixed, two-dimensional object. Rather, the central imagery is the crystal, which combines symmetry and substance with an infinite variety of shapes, substances, transmutations, multidimensionalities, and angles of approach. (p. 934 as quoted in Glesne, 2011, p. 47)

Despite the messiness implied in such an understanding of the research process and the inherent difficulties in attaining any validation, certain strategies were employed to contribute to the trustworthiness of the claims made in this study.

Firstly, my prolonged engagement with the primary participants contributed to our building relationships of confianza or mutual trust, a term borrowed from Moll and Gonzales (1993). A longitudinal approach, four years (and counting), enabled me the requisite time to build such rapport. A protracted study also allowed us the time to bridge our personal worlds and for data saturation.

Over the duration of the study multiple colleagues, friends, and family members were able to "hang-out" with my primary participants. Such meetings not only strengthened our relationship but also provided new insights and "alternative interpretations" (Stake, 1995, p. 113). Since I was working with an ethnic group that was foreign to me, the insights of other ethnicities, genders, and ages proved invaluable in challenging my own assumptions and biases. I am especially indebted to my Asian friends and colleagues who offered me invaluable interpretations of cultural behaviors and mores that often demystified some of my own interpretations.

The findings addressed in this particular study were also informed by my larger study on Karen resettlement described earlier. In the larger study we - three brothers from one Sandville family and myself - were able to visit and interview many Karen adolescents $(n=28)$ and adults $(n=42)$ from other Karen communities. We also distributed and collected questionnaires for both adolescents $(n=37)$ and adults $(n=50)$ that helped give us basic demographic information on Karen communities in the communities visited. The opinions and concerns of these participants also helped support the validity of the claims made in this paper.

\section{The Karen of Sandville, Georgia}

The Karen began arriving in Sandville, GA in 2006. A non-profit Christian service community that offers assistance to sponsoring agencies to resettle refugee families, resettled the initial family in the area in late 2006. The community grew from that first family (five members) to 12 families (54 members) by October, 2013. The members of two extended families account for 45 of the 54 Karen residents in the area. Each of the families is employed at a nearby chicken processing plant. The burgeoning Karen community now has an active Karen church (they rent a vacant church) and a Karen grocery store that sells Thai and Karen products. 
Gilhooly - Lessons Learned

Each of the Sandville-Karen families resettled to the United States from Mae La Refugee camp, the largest camp serving Karen and other ethnic minorities along the Thai-Burma border. Each of the families spent between ten and twenty years in Mae La and/or other camps. The education levels of all the Karen adults with school-aged children in Sandville vary; eight adults reported no formal education while six attended primary school and a one attended high school. All of the adults can read, speak, and write Sgaw Karen and four adults can speak, read, and write in English with varying degrees of proficiency.

According to the U.S. Census, the county, at 3.7\%, is well below the state average of $12.9 \%$ non-English speaking population. The county of approximately 14,000 is predominantly white $(80 \%)$ and $17 \%$ Black. The Karen community in Sandville represent the entire Asian population in the county. Although the elementary and high schools each had an ESL teacher prior to the arrival of Karen students, the district was unprepared for the arrival of such a unique population as the Karen. One ESL teacher explained the arrival of Karen students in her school this way when asked about her preparedness for their arrival:

I didn't hear about it. All of a sudden, one day, this man in a Karen outfit with no shoes met me in the high school office and told me what happened. I'm so glad he did that. I had never heard of the Karen before that morning. (Anonymous teacher, personal correspondence, 2011, Georgia)

Such lack of awareness was a common theme expressed by teachers and a primary motivation for this paper.

\section{Findings}

In order to better contextualize the Karen story in the U.S., I begin my findings section with background information on the process of resettlement from Thailand. The following section pertains to Karen educational experiences in the camps and resettlement to the U.S. based on the experiences of my focal Karen community.

\section{Karen Educational Experiences in the Camps}

One of the major reasons cited by Karen adults when asked why they chose to resettle to the U.S. was education for their children. One Karen father of three children expressed a common sentiment expressed by parents in regard to their motivations to resettle:

Karen people they go to U.S. and Australia, somebody go Norway for kid. In camp they no have chance to go school, college, and learning. I want my kid go to school and learning. Here [U.S.] they can do. (Wah Htoo, 2012, Georgia)

Interestingly, the Sgaw Karen in particular have a long history with formal, westernized, education as evidenced by the establishment of the Karen Education Society in 1860 (Mason \& Reynard, 1862). Most early missionary descriptions of the Karen offer some account of the Karen commitment to education with the emergence of mission schools (Mason \& Reynard, 1862; McMahon, 1876; Po, 1928; Smeaton, 1887). Such high regard for education is also found in more contemporary accounts (Baron et al., 2007; Moonieinda, 2010; Thawnghmung, 2012). Importantly, both boys and girls benefited from schooling as missionary schools were established for both. 
Gilhooly - Lessons Learned

In Mae La Camp, the largest of all refugee camps along the Thai-Burmese border, the Karen Education Department (KED) and the Karen Teachers Group (KTG) have created a relatively "good and diverse" education system according to Karen scholar Ardeth Thawnghmung (2012). She writes, "Mae La Camp supports 18 nursery schools, 13 elementary schools, three middle schools, four high schools, two Bible schools, and a continuing education program" (p. 81). Other camps have less education opportunities (Baron et al., 2007). For a glimpse into a typical camp classroom visit http://youtu.be/wAih5HTPpRE and for a look into the ad hoc Karen education efforts back in Karen State, Burma visit http://youtu.be/L96-F6ln22s. Schooling in the camps is very much unlike American-style teaching and learning.

\section{Teacher is Boss}

The teaching methods in the camps are based on what Moonieinda (2010) describes as "rote learning" (p. 42). One Karen adolescent's, Eh Htoo, account of his education in the camp school was indicative of many descriptions:

Not like here. Everyone must say and copy teacher, like that. Here [the U.S.] teacher want you talk but in camp, never. You talk, you maybe get hit. They say like Bible with stick parent can do, it okay to hit. Teacher hit for many thing like be quiet, no listen, like that ... to me teacher is boss. (Eh Htoo (pseudonym), Age 19, Georgia, 2011)

As Eh Htoo suggests, schooling and classroom management are very different from their American classroom experiences. I have found Karen students to be highly respectful toward their teachers and unaccustomed to speaking in class. Importantly, many Karen attend Bible classes or Karen language classes conducted by Karen teachers in the evenings and weekends in the U.S. where similar teaching methods reinforce cultural preference for strict discipline and silence. Finally, as McBrien (2005) suggested such silence may be compounded by student's fear of ridicule and harassment for their non-native English accents (p. 343).

\section{The Silent Karen}

Those working with the Karen need to recognize Karen attitudes and cultural norms when it comes to self-expression, especially between youth and adults. The Karen I have worked with are not accustomed to expressing concerns, fears, or frustrations to those in authority. In my experience I have found the Karen to be very reticent and unwilling to question or express themselves and, as one Karen adolescent put it, "They stay quiet, they want no trouble!" (personal correspondence, 19-year-old Karen male, Georgia, 2011). Their reticence is not surprising when we consider their historical oppression, flight from Burma, and protracted stay in refugee camps.

As a minority hill tribe in Burma long subjected to oppression, the Karen have long maintained distance and preferred to remain in relative isolation. This was further reinforced in the refugee camps where they were also taught the importance of avoiding Thai officials. Karen cultural mores also make communication an issue.

The Karen Communities Foundation (KCF), a Karen organization in the U.S. promoting Karen causes, offers a telling account of Karen cultural norms when it comes to asking for assistance: 
Gilhooly - Lessons Learned

Karen people are extremely polite, considerate and deferential; this is even more important to those we perceive to have higher status. By virtue of being older, male, American, white, etc. you are of higher status. A Karen person does not want you to lose face by complaining about your help or to be seen as ungrateful for the aid they are getting by complaining. We also worry about burdening you with requests. The word to describe the cultural norm is "annade." "Annade" is best described as "I feel bad that you have to go out of the way to do something for me ... Not understanding our rights, not coming from a culture where individual rights are central, many Karen arrivals are unlikely to tell you if something is wrong unless it is extremely serious." (Karen Communities Foundation, 2011)

Consequently, Karen parents and students may avoid contacting or communicating with teachers, administrators, and other government officials. Interestingly, many Karen youth related stories to me told to them by their parents or grandparents about the dangers of drawing attention to oneself. In short, for the Karen, staying under the radar was a means of survival. However, such reluctance to ask for assistance or to question their child's teacher can lead to more Karen students falling through the cracks of the U.S education system.

\section{The Language Divide}

Most Karen children in U.S. schools speak Karen at home and most seem to prefer speaking Karen with siblings and Karen peers. However, many younger Karen will not be able to read and write any of the forms of Karen. Many parents complained about this loss of Karen literacy and a few communities have responded by offering Karen language classes for school-aged children.

Children, namely 1.5 and $1.25^{7}$ generationers (those who resettled at earlier ages), also have limited speaking ability in Karen. Parents often rated their younger children's speaking proficiency with a score of five or lower (on a scale of ten) ${ }^{8}$ and expressed frustration over communication issues such as the loss of spoken Karen and the inability of their children to read and write Karen. Moreover, it was not uncommon for younger Karen children to have very limited Karen vocabularies, compromising parent-child communication.

Studies suggest that this discrepancy in language ability between generations can further the gap between parents and children (Lee et al., 2010; Nguyen \& Williams, 1989; SmithHefner, 1993). This cultural dissonance, where youth acquire language and understanding of the host culture faster than their parents, has been well documented in other immigrant communities. Like other Southeast Asian refugee groups before them (i.e. Hmong, Khmer, Laotian, and Vietnamese), Karen youth are acculturating faster than their parents. As younger children become socialized in schools, they are losing some of their heritage language. Studies on other Southeast Asian groups contend that such heritage language loss can be detrimental to academic achievement and healthy adaptation (Bankston \& Zhou, 1995; Rumbaut \& Ima, 1988).

Furthermore, there is widespread evidence that bilingualism has a positive effect on educational outcomes (Portes \& Schauffler, 1994; White \& Glick, 2000), regardless of immigration status, and that bilingualism may buffer the effect of coming from a lower socioeconomic background (Rumberger \& Larson, 1998). More studies are warranted on the role heritage language loss is playing in Karen and other refugee communities ${ }^{9}$. 


\section{Parent Involvement in Schooling}

One of the major concerns of new immigrants and the schools attempting to accommodate them is the lack of parental involvement in their children's schooling. A large corpus of studies suggest that parental involvement is a key factor in immigrant student graduation rates (Anguiano, 2004), psychological well-being (Kia-Keating \& Ellis, 2007), and overall academic achievement (Blakely, 1983; Henderson \& Berla, 1994; Rumbaut \& Ima, 1988; Siu \& Feldman, 1996; Zhou \& Bankston, 2000). Lack of parental involvement has been a major concern witnessed with Karen families in Sandville.

The disconnect between immigrant parents and schools has been well documented (Blakely, 1983; Hones, 2002; Siu \& Feldman, 1996). Karen parents repeatedly expressed to me the desire for their child to do well in school and attend college. However, none of the parents in my focal community had ever attended a teacher-parent conference, and only one teacher had visited any of the children's homes. Parents cited lack of English speaking ability, knowledge about American style education, and transportation as the as primary reasons for their lack of involvement. A corollary of this disconnect was that Karen students became solely responsible for their and their younger siblings' education.

The lack of parental involvement led to two troubling outcomes. First, students were found unprepared to navigate the school system on their own. Second, teachers and counselors were also unprepared to meet their unique needs. For example, students often missed important announcements or were unaware of school policies, course offerings, and the possibilities of participating in extracurricular activities. Students often signed their and their younger siblings report cards and other school documents.

The lack of parental involvement may be a cultural norm (see Blakely, 1983 on Southeast Asian parental attitudes towards school) as many Southeast Asian parents view schools as solely responsible for their children's education. Such a belief is exemplified when considering one American teacher's description of Karen parents. "Some parents [Karen] will discipline their children if we call, but for the most part they expect us to take care of everything" (High school teacher, personal correspondence, June, 2012). It is clear that Karen parents are marginalized from their children's education and that Karen children are often responsible for navigating the American education bureaucratic system alone.

\section{Teacher Perceptions}

Sgaw Karen students were reported to be well behaved and respectful by teachers interviewed. I found my Karen students to be respectful and deferential but unaccustomed to dialoguing with their teacher. They also spoke of saying little in their American classes. Although teachers expressed frustration with their lack of requisite skills, initially the Sgaw Karen students seemed well received in schools. Teachers reported only isolated instances concerning disciplinary issues.

As with Kenny and Kenny-Lockwood's (2011) study of Karen in the northeastern U.S., I found Karen academic performances to be very mixed. One community in Tennessee ${ }^{10}$ with over 130 Sgaw Karen families is finding some encouragement from Sgaw Karen graduation rates. One teacher writes: 
Gilhooly - Lessons Learned

We currently have a 100 percent Sgaw Karen graduation rate, with 16 students graduating last year. One of our students was in the top 10 percent of the graduating class, and we've been able to hire her as an assistant at the school. (Anonymous teacher, personal communication, July 3, 2012)

Such high graduation rates were not indicative of other communities. Again, like Kenny and Kenny-Lockwood's (2011) study, I found very mixed results related to graduation and dropout rates. Although this one community boasts excellent academic outcomes, I witnessed a great discrepancy between Karen students' grades and their actual academic abilities.

\section{What is an $\mathrm{A}$ ?}

Many of the Karen children I worked with received high grades on report cards despite their lack of ability in the various disciplines. The case of one Sandville High School student best exemplifies this phenomenon. Ler Say (pseudonym) was a 19-year-old Karen adolescent who moved to the United States when he was 13 years old. Since arriving he has advanced to the succeeding grade every year. However, it was clear to me as his tutor that Ler Say was well below his grade level in reading and writing and that he struggled with spoken English. One study session demonstrated the discrepancy between his grade level and skill level.

One study session I had Ler Say and each of his siblings take practice exams. Whereas his brothers and sister were preparing for the Criterion Referenced Competency Tests (CRCT) ${ }^{11}$ in advance of their scheduled state mandated tests, he was preparing to take the Georgia High School Graduation Test. Accidently, Ler Say took a copy of his brother's first grade reading test rather than his tenth grade test. It wasn't until he completed the practice test that I realized the mistake. I didn't inform him of the error and decided to see how he did, he missed four out of the ten questions. When we reviewed the test together I realized two important things.

First, Ler Say struggled with reading at a first grade level. Second, much of his confusion surrounded the title of the reading passage, "Setting the Table." As a young man coming from a culture that does not use utensils (the Karen eat with their fingers) and whose home language was not English, he had never been exposed to the expression "setting the table." Therefore, from the outset he was at a disadvantage, as he could not contextualize the reading passage the way an American child might. As an American child I was never formally taught to set the table; rather, I learned in context by watching my parents and siblings arrange the utensils, cups, and plates. The more I considered this example, the more I began to see similar cases with his siblings. It was clear that he and his siblings were unaware of the many idioms, phrasal verbs, and colloquialisms of "home."

At the time Ler Say was in the tenth grade, and each of his report cards indicated he was not only passing but excelling in school. However, his report card belied the reality that he struggled with basic skills. Whether his grades reflected his effort, the sympathy of teachers, his shy and deferential demeanor, or an unwillingness to retain him, Ler Say was not served by his high grades. He, like other older Karen in his community, ended up failing repeated attempts at mandatory state graduation exams and was unable to graduate from high school.

Ler Say's story is not unique to this community or to the many immigrant students' school experiences (Blakely, 1983; Rumbaut \& Ima, 1988). One can empathize with teachers as well. Ler Say was a model student in many ways. He was well behaved, maintained perfect attendance, and worked hard. For me, the issue is less about teachers assigning unrealistically high grades and more about the system they are trying to work within. At some level, Ler Say 
Gilhooly - Lessons Learned

was passed on because no one knew what to do with him. This issue will be taken up later in the implication section of the paper.

\section{What's in a Name?}

Gunn, Brice, and Peterson (2014) contend that by learning students' names teachers can demonstrate respect for the student's home culture and help children "fit in." I have witnessed much confusion regarding Karen names and believe it is an important element in respecting home culture but also respecting individual students' identities.

Karen children may have a variety of names, some of which defy their ethnic origin. They may be given Burman, English, and Karen names, or a combination of them. For example, a Karen female may be named Julie Paw (Julie Flower) and her brother Bright Htoo (Bright Gold), while a third may simply be named Wonderful. Many of the Karen children born in the United States are given such mixed names.

According to Ananda Rajah (2002), many Karen have what are called "event names." These names describe "events" at the time of the baby's birth. For example, a boy born June 2 may be called June Two; while another boy, who was born while preparing to flee oncoming Burmese troops, might be simply named Ready. Other names may reflect favorable qualities, like Law Eh (handsome). Many Sgaw Karen names are taken from the Bible. Names likes Grace, Esther, Sara, Mo Say (Moses), Pol Lu (Paul) and Christ are common. Other Karen names depict natural objects such as flowers, stars, money, and love (see Table 1.2).

Karen also use honorifics (Moonieinda, 2010) and most Karen children will be accustomed to referring to adults, especially teachers, with an appropriate honorific. The female honorific Naw prefaces a female name, such as Naw Kayo Paw (Ms. Cherry Flower). And the male honorific Saw is used with adult males, for example, Saw Htoo Wah (Mr. Gold White). Importantly, Karen students are accustomed to using the honorific Thera when addressing teachers and may be uncomfortable with less formal appellations such as Mr. Daniel or Ms. Maya. Nevertheless, most Karen refer to each other with a nickname or pet name usually designated by parents, grandparents, or a family friend. Such nicknames usually reflect special qualities or characteristics. For example, a common nickname for a diminutive Karen boy is Chit Poe (Little One). Other Karen may be nicknamed according to their complexion, weight, or character. Table 1.2 provides some sense of the variety and beauty of Karen names. 
Gilhooly - Lessons Learned

Table 1.2

Sgaw Karen Names

\begin{tabular}{ll}
\hline Sgaw Karen (Gender) & English \\
\hline Kayo Paw (Female) & Cherry Flower \\
Sa Ra (Female) & Sarah Threa \\
Eh Ser Paw (Female) & Love Sweet Flower \\
Christ Mu Htoo (Female) & Christ Life Gold \\
Grace Taw & True Grace \\
Hser Gay Htoo (Female) & Sweet Good Gold \\
Ler Moo (Male) & True Life \\
Htoo Wah (Male) & White Gold \\
Sher Tah Taw (Male) & Sweet True Heart \\
Eh Taw (Male) & True Love \\
June Two (Male/Female) & June Second \\
Lucky Moon (Male/Female) & \\
\hline
\end{tabular}

Significantly, the Karen do not have surnames. Their names are neither patronymic nor matronymic. When they arrive in the United States, the final syllable of their name becomes a surrogate surname on all official documents. Thus, someone named Moo Tha Wah becomes Moo Wah on all official documentation (Tha becomes a middle name). His brother, Moo Say Wah might have the same official name, Moo Wah. This can cause confusion and misidentification. Moreover, teachers and school officials need to recognize that students might be biologic siblings despite not sharing a common surname. ${ }^{12}$ Those who work with the Karen should ask their students what they prefer to be called; usually the nickname is preferred as it is what they identify with at home and with friends.

\section{Sgaw Karen Language}

The Sgaw Karen writing system is relatively new. Prior to the introduction of a Karen script, devised by American missionary Dr. Wade in 1834, the Karen had no written orthography (Marshall, 1992; South, 2011; Thawnghmung, 2012). The American missionary enterprise was extremely efficient in educating the Karen in this new script and made literacy an early missionary goal (Falla, 1991; Lewis, 1924). Later, other Christian missionaries and Buddhist scholars divided the Karen along religious and linguistic lines by creating competing Karen writing systems (Delang, 2000; South, 2011; Smith, 1999). There are over 12 non-mutually intelligible but related Karen dialects with at least nine different scripts (Cheesman, 2002; South, 2007). Sgaw Karen has become the Karen lingua franca in the refugee camps (Baron et al., 2007; Brees, 2010) and post resettlement communities with Pwo and Sgaw Karen often interacting in Sgaw Karen (field notes, Karen New Year celebration, January 2012). The majority of Karen children entering U.S. schools will speak Sgaw Karen at home. The characteristics of the Sgaw Karen language are singular in the region and deserve a brief description. Despite the paucity of studies that address teacher awareness of language characteristics of their students' L1 (first language) in English as a second language classrooms, the author argues that teacher awareness of certain linguistic features of their students may help address grammar and phonemic issues from the outset.

Harry Marshall's (1922) ethnographic work on the Karen provides some of the key linguistic features of Sgaw Karen that may help inform teachers working with Karen students.

Journal of Southeast Asian American Education \& Advancement, Vol. 10 (2015) 
Gilhooly - Lessons Learned

The Sgaw Karen alphabet contains 25 consonants and 10 vowels and has 6 different tones (Marshall, 1992). Unlike more recently created orthographies that use Roman script, the most commonly used Sgaw Karen script uses Burmese letters (Hayami, 2004). As such, the Sgaw Karen alphabet is "a perfect phonetic alphabet" according to Marshall (1922, p. 31). Consequently, Karen students struggle with the notion that English letters have various pronunciations.

Sgaw Karen orders sentences much like English with subject-predicate-object ordering. Accordingly, English syntax has not been found to be a major obstacle for Karen students. However, there are a few linguistic differences between English and Sgaw Karen that may apprise teachers.

First, in Sgaw Karen, there is an absence of final consonant sounds (Marshall, 1992). This absence of a final sound has been evidenced frequently during my work as a tutor with Karen students who often do not pronounce the final consonant of English words, adversely affecting their pronunciation. For example, the words little, liter, and litter will often be confused. For the fist few months I thought my students were simply mumbling, until I realized they were simply not pronouncing final consonants because they did not exist in their first language.

Second, Sgaw Karen verbs are "almost always transitive" (Marshall, 1992, p. 33) and, more importantly, there is no tense system. All of my older Karen students struggled with verb tenses (e.g., I eat yesterday. and; I doing homework every day.). Third, in Sgaw Karen there are no sounds compatible to the English letters $g, j, v$ or $\mathrm{z}$ and therefore are frequently problematic sounds for Sgaw Karen students to pronounce. The Center for Applied Linguistics also notes that Sgaw Karen is monosyllabic and tonal and therefore difficult to Romanize accurately (Baron et al., 2007). Therefore, transliteration is not always possible or advisable.

Fourth, Karen script does not differentiate between lower case and upper case letters. I have found that the English rules for capitalizing to be a major obstacle for older Karen students. Invariably, Karen children will write their names in lower case letters. For example, hser mu htoo and Hser eh taw are common ways I have found my students writing their names. Such issues pertaining to writing were evidenced more with older (1.75 generation) Karen who read and wrote in Sgaw Karen and had limited expose to English.

Acknowledgement of these linguistic differences between Sgaw Karen and English may have implications for classroom teachers, curriculum designers, speech pathologists, ESL teachers, and tutors.

\section{Gender}

Women have traditionally played a very active role in Sgaw Karen village life and are important actors in Sgaw Karen social life (Falla, 1991; Zan, 2008). Since the arrival of American missionaries, Karen women have held important positions within Karen society. Many Karen girls were provided the same education as boys and have served important roles in the insurgency (Zan, 2008). Louisa Benson Craig, a former Miss Burma, was one of the many Sgaw Karen women who held important military positions within the insurgency and later in the Karen Diaspora community in the U.S. Today, Karen women, such as the award-winning author, Zoya Phan (see Phan, 2010), are important spokespeople in the Karen Diaspora community. However, like Watkins, Razee, and Richters' (2012) study of Karen women in Australia, I found some troubling trends related to Karen women and girls in the U.S.

First, I have found that Sgaw Karen adolescent girls are dropping out of high school at higher rates than boys. Four out of the five adolescent girls related to the community dropped out 
Gilhooly - Lessons Learned

of high school before finishing grade 10. The sister and sister-in-law of one family, and two cousins all dropped out school in order to marry. This is not surprising in light of similar accounts at the camps related by Su-Ann Oh and Marc Van der Stouwe (2008). Their research on Karen education in the camps reveals high dropout rates amongst girls in camp schools. They write of Karen girls in the camps: "The threat of exclusion from education does not, however, discourage youths from marrying. ... Of the 28 young women in our sample, all but two women had dropped out of school because of pregnancy" (p. 601). Male dropouts were also documented, but in each of these cases, employment was cited as the primary reason for quitting school.

Adolescent girls were also more burdened with housework compared to brothers (Watkins et al., 2008). As in other Southeast Asian communities (see Zhou \& Bankston, 2001 on the role of adolescent girls in the Vietnamese community), girls were responsible for caring for younger siblings, cleaning the house, and cooking, often at the expense of doing schoolwork. Again, more studies are warranted on Karen girls' education in the United States.

\section{Conclusions and Implications}

Josef Joffe, the publisher-editor of the German weekly Die Zeit, suggests in his new book, "The Myth of America's Decline," that the United States will continue to be a world leader because, in part, of its immigrants. It is clear to this author that the U.S. has benefitted from its diversity but that too often the first and second generations (and those in-between) are left behind because teachers, schools, and state education policies are not meeting their needs. The following offers suggestions for ways that schools and teachers can begin to address this latest immigrant population and concludes with ways in which teachers can begin to use these children's' funds of knowledge in their instruction.

First, schools must first recognize which ethnic groups under the label Burmese are being resettled in their schools. Teachers and school administrators need to acknowledge the unique history and culture of their Karen students. In urban schools, students from each of the Burmese ethnic groups (Chin, Karen, Kachin, and Karenni) may be arriving. Each of these groups is singular and Karen and other minority groups may be offended if referred to as Burmese because of the historical animosity and 60-year civil war. Schools need to acknowledge their differences and make a concerted effort to educate their staff, students, and community about their new neighbors, students, and classmates. Moreover, such cultural training should include stakeholders from the community.

By facilitating more interaction with parents, schools will help mitigate the negative consequences associated with parental marginalization, misunderstandings about school regulations and policies, and the lack of minority student involvement in extracurricular programs. Schools can begin by offering information sessions for parents about American-style grading, discipline, homework, report cards, state and national exams, and educational options post-high school. Parents must also be informed about ways in which they can supports their children's learning. Such programs can help parents regain some autonomy over their children's education.

Parents must also recognize their rights and responsibilities in their children's education and be shown ways they can participate and keep track of their child's progress. Too often, nonEnglish speaking parents falsely assume their child is managing well because of their apparent English proficiency. Bridges must be built between immigrant communities and schools. News travels fast and I have witnessed how quickly information is shared within one Karen community. In every community visited, I was able to find at least one Karen adult who spoke English proficiently. These adults must be identified and utilized by schools.

Journal of Southeast Asian American Education \& Advancement, Vol. 10 (2015) 
Gilhooly - Lessons Learned

Teachers must also recognize the burden these children face as they attempt to navigate their and their younger sibling's education without support. Awareness of their students' home life (i.e., parental education, employment status, housing conditions, etc.) can help teachers better understand and address their students' emotional, psycho-social needs (Bronstein \& Montgomery, 2011).

Furthermore, schools need to address the mismatch between students' grades and their actual skill levels. As was demonstrated with the case of Ler Say, high grades and promotion to the next grade level only provided him and his parents with a false sense of success. His eventual inability to graduate led to feelings of hopelessness and limited employment prospects. Sadly, Ler Say's case has become the norm for many resettled refugee children who resettle in their early teens (Blakely, 1983). Ler Say is currently unemployed and reports that he "sleep all day and very sad with nothing to do" (personal correspondence, November, 2013). Schools need to acknowledge this phenomenon and find alternative methods to meet the needs of such students. The first step is awareness.

It was clear to me as the children's tutor that each of the children had few authentic language speaking opportunities outside of school. I contend that this, too, is a community wide issue, and that willing members of the community (American) should be utilized. Partnerships might be made between refugee communities and the surrounding community. The support of local churches, retirement homes, and universities may help build bridges. States and schools need to recognize the importance of healthy acculturation for the future of their children and communities.

Next, state departments of education must reconsider policies regarding universal graduation tests and recuse second language students from these tests. Such tests are inherently unfair and culturally biased (Wong, 2006). Alternative means of graduation should be made available (i.e., waivers) and, most importantly, explained to Karen students and their parents.

Schools should also consider ways to provide a blend of both sheltered and mainstream classes to English language learners. My opinion matches the findings of Kenny and LockwoodKenny (2011) who suggests that Karen students are often treated with "benign neglect" in schools after the novelty of their arrival dissipates. Overall, teachers and school officials need to recognize the manifold realities refugee families face as they cope with resettlement and to acknowledge and incorporate their funds of knowledge. Teachers are encouraged to view students' homes not only in terms of their physical condition but must recognize the funds of knowledge that are present in these homes. These funds of knowledge may be utilized to foster lessons or assignments that can draw on students' home life while valuing the student's home culture and immigration experience.

\section{Ideas for Teachers: Utilizing Karen Funds of Knowledge}

Teachers can use the students' cultural background or funds of knowledge in their curriculum. For example, with younger students teachers can use students names as a means to work on pronunciation, cross-cultural understanding, and, most importantly, to address the elephant in the room. Karen students continually reported being made fun of because of the uniqueness of their names. This is often the case with immigrant students and can heighten feelings of loneliness and isolation (Gunn, Brice, \& Peterson, 2014). However, such ridicule can be eliminated if the name issue is addressed.

By addressing students' names teachers can "foster early literacy learning, and nurture children's sense of personal cultural identity through intentional planning of instructional activities that highlight children's names" (Gunn, Brice, \& Peterson, 2014, p. 175). Such 
Gilhooly - Lessons Learned

nurturing is also crucial for other ages and can be accomplished simply by asking and observing students. Teachers can have students draw or paint artistic representations of their names and/or Karen students can help other students choose a Karen name based on their preferences. Also, teachers can use a naming jar (see Choi, 2013) as a means of acknowledging all students' names.

Teachers can also capitalize on the many strengths Karen students bring to class. In my time with the Karen, I have become aware of their appreciation for and ability in the arts, namely, drawing and music. Every home visited had at least one guitar and all males demonstrated some degree of skill. In each case, they were self-taught or taught informally by their father or a male relative. Although I only witnessed one Karen woman playing guitar, Karen girls and women are renowned for their singing.

Every Karen church visited had an active youth and adult choir. Surprisingly, the Karen often lose their shyness when singing or playing on stage. I have been amazed to witness some of my most reticent Karen students singing in front of an audience of many hundreds. Teachers and communities should try and incorporate music into their lessons and curricula. Singable books can be an excellent tool for incorporating songs as part of the reading curriculum for young children (see Haynes \& Smallwood, 2008, for more information).

Moreover, Karen youth have become savvy in creating and disseminating their own music via the web (Gilhooly \& Lee, 2014). Christian, pop, rock, hip-hop and heavy metal songs are all favorites of Karen youth. YouTube is replete with Karen-made music videos attesting to their musicality and adeptness at using new technologies. The children and adolescents I worked with also demonstrated great interest in drawing and painting. Art classes may provide Karen students another avenue to succeed in courses or after school programs that are not language focused. It may allow them opportunities to build affinity groups as well. Most importantly, they will have opportunities to socialize as well as demonstrate their abilities.

Sports may be another means of better integrating Karen youth in schools and communities. The Karen have a passion for soccer, volleyball, and cane ball and are learning to play basketball and baseball. Karen students would relish the opportunity to demonstrate cane ball to their classmates. Like music, such activities may entice Karen students to participate in extracurricular activities. In my focal community none of the children participate in sports or music programs despite their expressed interest. Schools can use the lure of musical instruments or musical production, art classes, choir, or band to entice Karen students to participate in extracurricular activities and socialize with American peers.

Agriculture or technology classes can also draw from Karen knowledge with farming and mechanics. As an agrarian people, the Karen are skilled at farming, hunting and fishing, and animal husbandry. Schools with agriculture programs can work on initiatives that draw on these traditional skills. Because of their protracted confinement in refugee camps the Karen have become very resourceful and demonstrate ability in small motor repair, appliance repair, as well as making and fixing an assortment of tools. These students would benefit from classes that help promote skills that can lead to direct employment.

No discussion of the Karen is complete without some recognition of the role of church within the family and community. The Sgaw Karen are very devout and the church is the center of many Karen villages in Burma, the camps, and communities in the U.S. They are also sites for multiple forms of knowledge. At church, Karen children not only learn doctrine but are encouraged to be involved in youth choir, Bible study, and community outreach where they help organize and conduct Karen functions. They also learn academic skills such as memorization, recitation, and public speaking that can help them in their school studies. I have found Karen students to be very capable in memorizing and reciting poems and songs. There rich oral culture may be integrated into English language arts classes or in public speaking. 


\section{Gilhooly - Lessons Learned}

Immigrant families like the Karen bring many abilities, knowledge, and stories to our classrooms and communities. They each come from rich cultural backgrounds that can enrich the school and wider community. This can only be achieved when educators gain awareness into the students' individual and collective stories. Therefore, culturally responsive teaching includes awareness of the complex cultural, historical, linguistic, personal, psychological, and social aspects that each student bring with them into our schools and classes. 
Gilhooly - Lessons Learned

\section{References}

Anguiano, R. P. V. (2004). Families and schools: The effect of parental involvement on high school completion. Journal of Family Issues, 25(1), 61-85.

Bankston, C. L. I., \& Zhou, M. (1995). Effects of minority-language literacy on the academic achievement of Vietnamese youths in New Orleans. Sociology of Education, 68(1), 1-17.

Baron, S., Okell, J., Myat Yin, S., Vanbik, K., \& Swain, A. (2007). Refugees from Burma: Their backgrounds and refugee experience. (No. 21). Washington DC: Center for Applied Linguistics.

Bauböck, R., \& Faist, T. (2010). Diaspora and transnationalism: Concepts, theories and methods. Amsterdam, Netherlands: Amsterdam University Press.

Blakely, M. M. (1983). Southeast Asian refugee parents: An inquiry into home-school communication and understanding. Anthropology \& Education Quarterly, 14(1), 43-68.

Brees, I. (2010). Burden or boon: The impact of Burmese refugees on Thailand. Whitehead Journal of Diplomacy \& International Relations, 11(1), 35-47.

Bronstein, I., \& Montgomery, P. (2011). Psychological distress in refugee children: A systematic review. Clinical Child \& Family Psychology Review, 14(1), 44-56. doi:10.1007/s10567010-0081-0

Charmaz, K. (2006). Constructing grounded theory: A practical guide through qualitative analysis. London, UK: Sage.

Cheesman, N. (2002). Seeing 'Karen' in the union of Myanmar. Asian Ethnicity, 3(2), 199-222. doi:10.1080/14631360220132736

Choi, Y. (2013). The name jar. New York, NY: Random House LLC.

Corbin, J., \& Strauss, A. (Eds.). (2008). Basics of qualitative research: Techniques and procedures for developing grounded theory. Thousand Oaks, CA: Sage.

Cusano, C. (2001). Burma: Displaced Karens like water on the khu leaf. London, UK: Luto Press.

Delang, C. (Ed.). (2000). Suffering in silence: The human rights nightmare of the Karen people of Burma (1st ed.). Parkland, FL: Universal Publishers.

Falla, J. (1991). True love and Bartholomew. New York, NY: Cambridge University Press.

Gay, G. (2002). Preparing for culturally responsive teaching. Journal of Teacher Education, 53(2), 106-116.

Gay, G. (2010). Culturally responsive teaching: Theory, research, and practice. New York, NY: Teachers College Press.

Gilhooly, D., \& Lee, E. (2014). The role of digital literacy on refugee resettlement: The case of three Karen brothers. Journal of Adolescent \& Adult Literacy, 57(5), 387-396. doi:10.1002/JAAL.254.

Glesne, C. (2011). Becoming qualitative researchers: An introduction (4 ${ }^{\text {th }}$ ed.). Boston, MA: Pearson.

Gonzalez, N., Moll, L., Tenery, R. M., Rendon, A., Gonzalez P., Amanti, C. (1995). Funds of knowledge for teachers in Latino households. Urban Education, 29(4), 443-470.

Gonzalez, N., Moll, L. C., Floyd-Tenery, M., Rivera, A., Rendon, P., Gonzales, R., \& Amanti, C. (1993). Teacher research on funds of knowledge: Learning from households. Washington, DC: Center for Research on Education, Diversity \& Excellence.

Gonzalez, N., Moll, L. C., \& Amanti, C. (2005). Funds of knowledge: Theorizing practices in households, communities, and classrooms Mahwah, NJ: L. Erlbaum Associates. 
Gilhooly - Lessons Learned

Gunn, A. A., Brice, A. E., \& Peterson, B. J. (2014). Ideas for the classroom: Culturally responsive teaching: Exploring children's names and cultural identities. Childhood Education, 90(2), 174-176. doi:10.1080/00094056.2014.894836

Harriden, J. (2002). "Making a name for themselves": Karen identity and the politicization of ethnicity in Burma. Journal of Burma Studies, 7, 84-144.

Hayami, Y. (2004). Between hills and plains: Power and practice in socio-religious dynamics among Karen. Kyoto, Japan: Kyoto University Press.

Haynes, E., \& Smallwood, B. (2008). Singable books: Sing and read your way to English proficiency. CAL Digest, 34, 1-4.

Henderson, A. T., \& Berla, N. (1994). A new generation of evidence: The family is critical to student achievement. Columbia, MD: National Committee for Citizens in Education.

Hones, D. F. (1999). Crises, continuity, and the refugee. Journal of Contemporary Ethnography, 28(2), 166-198.

Hones, D. F. (2002). American dreams, global visions: Dialogic teacher research with refugee and immigrant families. Mahwah, NJ: L. Erlbaum Associates.

Karen Communities Foundation. (2012). Considerations for individuals and agencies working with the Karen people in the United States. Retrieved from http://www.karensusa.org/index_files/Page762.html

Kia-Keating, M., \& Ellis, B. H. (2007). Belonging and connection to school in resettlement: Young refugees, school belonging, and psychosocial adjustment. Clinical Child Psychology \& Psychiatry, 12(1), 29-43.

Kenny, P., \& Lockwood-Kenny, K. (2011). A mixed blessing: Karen resettlement to the United States. Journal of Refugee Studies, 24(2), 217-238. doi:10.1093/jrs/fer009

Lee, R. M., Choe, J., Kim, G., Ngo, V., Park, Y. S., Kim, B. S. K., \& Ju, C. M. (2010). Asian American family conflicts scale. Asian American Journal of Psychology, 1(1), 67-79.

Lewis, J. (1924). The Burmanization of the Karen people: A study in racial adaptability. Chicago, IL: The University of Chicago Press.

Malseed, K. (2008). Networks of noncompliance: Grassroots resistance and sovereignty in militarized Burma. Journal of Peasant Studies, 36(2), 365.

Marshall, H. I. (1922). The Karen people of Burma: A study in anthropology and ethnology. Columbus, OH: Ohio State University Press.

Mason, E. H. B., \& Raynard, E. H. (1862). Civilizing mountain men: Or, Sketches of mission work among the Karens. London: James Nisbet.

McBrien, J. L. (2005). Educational needs and barriers for refugee students in the United States: A review of the literature. Review of Educational Research, 75(3), 329-364. doi: $10.2307 / 3515985$

McMahon, A. (1876). The Karen of the golden chersonese. London, UK: Harrison and Sons.

Milbrandt, J. (2012). Tracking genocide: Persecution of the Karen in Burma. Texas International Law Journal, 48, 63-101.

Moll, L. C., Amanti, C., Neff, D., \& Gonzalez, N. (1992). Funds of knowledge for teaching: Using a qualitative approach to connect homes and classrooms. Theory into Practice, 31(2), 132-141.

Nguyen, N. A., \& Williams, H. L. (1989). Transition from east to west: Vietnamese adolescents and their parents. Journal of the American Academy of Child and Adolescent Psychiatry, 28(4), 505-515.

Oh, S. A., \& Van der Stouwe, M. (2008). Education, diversity, and inclusion in Burmese refugee camps in Thailand. Comparative Education Review, 52(4), 589-617. 
Gilhooly - Lessons Learned

Phan, Z., Lewis, D., \& Phan, Z. (2010). Undaunted: My struggle for freedom and survival in Burma. New York, NY: Free Press.

Po, S. C. (1928). Burma and the Karens. London, UK: Elliot Stock.

Portes, A., \& Schauffler, R. (1994). Language and the second generation: Bilingualism yesterday and today. International Migration Review, 28(4), 640-661. doi:10.2307/2547152

Rajah, A. (2002). A 'nation of intent' in Burma: Karen ethno-nationalism, nationalism and narrations of nation. Pacific Review, 15(4), 517-537.

Refugee Processing Center (RPC). (2014). Refugee arrivals by region and country of nationality: Fiscal years 2001 to 2013. Retrieved from www.wrapsnet.org/Reports/InteractiveReporting/tabid/393/EnumType/Report/Default.as px?ItemPath=/rpt_WebArrivalsReports/MX\%20\%20Arrivals\%20for\%20a\%20Demographic\%20Profile

Richardson, L. (2000) Writing: A method of inquiry. In N. Denzin \& Y. Lincoln (Eds.), Handbook of Qualitative Research, (2 ${ }^{\text {nd }}$ ed., pp. 923-946). Thousand Oaks, CA: Sage Publications.

Rumbaut, R. G., \& Ima, K. (1988). The adaption of Southeast Asian refugee youth: A comparative study. San Diego, CA: San Diego State University.

Rumberger, R. W., \& Larson, K. A. (1998). Toward explaining differences in educational achievement among Mexican American language-minority students. Sociology of Education, 71(1), 68-92. doi:10.2307/2673222

Siu, S. F., \& Feldman, J. A. (1996). Patterns of Chinese American family involvement in young children education. ERIC Document Reproduction Service No. ED399346. Retrieved from http://files.eric.ed.gov/fulltext/ED399346.pdf

Smeaton, D. M. (1887). The loyal Karens of Burma. London, UK: K. Paul, Trench \& Co..

Smith, M. (1999). Burma: Insurgency and the politics of ethnicity. New York, NY: St. Martin's Press.

Smith-Hefner, N. (1993). Education, gender, and generational conflict among Khmer refugees. Anthropology \& Education Quarterly, 24(2), 135-158. doi:10.2307/3195722

South, A. (2007). Karen nationalist communities: The "problem" of diversity. Contemporary Southeast Asia: A Journal of International \& Strategic Affairs, 29(1), 55-76.

South, A. (2011). Burma's longest war: Anatomy of the Karen conflict. Netherlands: Transnational Institute Burma Center Netherlands.

Stake, R. (1995). The art of case study research. Thousand Oaks, CA: Sage.

TBBC. (2008). Scale and distribution of internal displacement. Retrieved from www.tbbc.org/idps.htm\#distribution

Thawnghmung, A. M. (2012). The "other" Karen in Myanmar: Ethnic minorities and the struggle without arms. Lanham, MD: Lexington Books.

Thawnghmung, A. M. (2008). The Karen revolution in Burma: Diverse voices, uncertain ends. Washington, DC: East-West Center.

Watkins, P., G., Razee, H., \& Richters, J. (2012). 'I'm telling you ... the language barrier is the most, the biggest challenge': Barriers to education among Karen refugee women in Australia. Australian Journal of Education (ACER Press), 56(2), 126-141.

White, M. J., \& Glick, J. E. (2000). Generation status, social capital, and the routes out of high school. Sociological Forum, 15(4), 671-691. doi:10.1023/A:1007515100190

Wong, S. (2006). Dialogic approaches to TESOL: Where the ginkgo tree grows. Mahwah, NJ: Lawrence Erlbaum Associates. 
Gilhooly - Lessons Learned

Worldwide Refugee Admissions Processing Services (WRAPS). (2014). Refugee arrivals by region and country of nationality: Fiscal years 2001 to 2010. Retrieved from http://www.dhs.gov/files/statistics/publications/YrBk10RA.shtm

Zan, S. (2008). Life's journey in faith: Burma, from rags to riches. Bloomington, IN: Author House.

Zhou, M., \& Bankston III, C. L. (2000). Straddling two social worlds: The experience of Vietnamese refugee children in the United States. (Evaluative Report No. 111). New York: ERIC.

Zhou, M., \& Bankston III, C. L. (2001). Family pressure and the educational experience of the daughters of Vietnamese refugees. International Migration, 39(4). 133-151.

\section{Notes}

${ }^{1}$ Burma or Myanmar? The State Law and Order Restoration Council (SLORC) military junta officially renamed the country "Myanmar Naing-ngan" in 1989 (South, 2008). However, ethnic minority groups and some governments, such as the United States, still use the old designation "Burma." This study follows the traditional usage of "Burma" as it was the only designation used by the Karen contributors to this paper.

${ }^{2}$ Burmese refers to all minority groups in Burma whereas Burman refers to the majority ethnic group in Burma. Burmese is also the appellation for the Burman language, the official language of Burma

${ }^{3}$ Burman refers to the majority ethnic group in Burma whereas Burmese refers to all ethnicities from Burma.

${ }^{4}$ The first Karen student, Theodore Thanbyah, graduated from an American university, the University of Rochester (New York) in 1871 (Martin, 2012).

${ }^{5}$ Some Karen Buddhists and Karen Muslims are also arriving.

${ }^{6}$ It is important to note that Karen armed groups, including the Karen National Liberation Army (KNLA) and Democratic Karen Buddhist Army (DKBA), have been accused on human rights violations, including forced conscriptions as a means to continue their insurgency (South, 2011, p.15)

${ }^{7}$ Drawing on Rumbaut's (1997) "decimal generations," 1.25 generation refers to those resettling from ages 13-17 and 1.5 as resettling between the ages of 6-12, and 1.75 refers to those who resettling 0-5.

${ }^{8}$ This was an informal scale where I would ask parents to assess their children's language ability according to the following; 10=excellent Karen, 5=fair Karen, $0=$ no Karen. I did not attribute any weight to the other numbers.

${ }^{9}$ As of May 2014, my focal community has begun a summer Karen school where students of all ages are being taught Karen reading and writing.

${ }^{10}$ I made the acquaintance of a teacher working with Karen students and we corresponded frequently exchanged information about the respective Karen communities from 2011 to 2012.

${ }^{11}$ All Georgia students from grades 1-8 took the CRCT until 2010-2011. From 2011-2012 the test is only given from grades 3-8. A passing score on the GHGT was mandatory for all Georgia students who entered high school before July 2011.

${ }^{12}$ To complicate matters more, I have recently heard reports of how some families bought new identities from the camps in order to resettle. It seems that as fewer and fewer Karen and other minorities are eligible for resettlement, registration for resettlement has premium value to those looking to resettle. Therefore, some children may be entering the United States with names acquired by the illegal procurement of papers in the camps. 


\section{Appendix}

\section{Sample Interview Questions \\ Interviews with Students}

1. Did you attend school in Burma?

2. Did you study English before coming to the USA?

3. Are in ESL classes?

4. Do you attend any regular (non-ESL) classes?

5. Do you have special English classes after school or tutoring at home?

6. Do you like school?

7. Do you have any American friends?

8. Do you ever get bullied? What does Bullying mean to you?

9. What classes are most difficult for you?

10. Do you plan on graduating?

11. What will you do after you graduate/ quit school?

12. Do you participate in school sports or activities?

13. What do you like/dislike about your school in US and Camps?

14. Did your teachers hit you in school?

15. What are the biggest differences between school in the USA and in the refugee camp?

16. What are your future goals?

\section{Interviews with Karen Parents}

1. What languages can you read and write?

2. Why did you choose to resettle?

3. What are you hopes and fears for your children?

4. What do you think of your children's' education?

5. Would you resettle knowing what you know now? Might you resettle in another country?

6. What has been the toughest part of resettlement?

7. Have you ever visited your child' school? Why or why not?

8. How do you know if your kids are doing well in school? Do you check homework? Reports cards?

9. Do you ever study English? Why, or why not?

10. Do you think it is acceptable for a teacher to hit a student?

\section{Interviews with American Neighbors}

1. How did you first meet the Karen people?

2. What was your first impression of the Karen?

3. In what capacity do you know or work with the Karen?

4. What do you think of as characteristics of the Karen people?

5. What problems do you see the Karen facing in the United States?

6. In what ways do you see the Karen successfully adapting to American culture?

7. In what way do you see Karen culture and American culture at odds?

8. Do you think that services for refugee populations like the Karen are working?

\section{Interviews with American teachers working with Karen}

1. What grade do/did you teach Karen students?

2. How many Karen students have you taught?

3. Did your school or district provide you any information about the Karen people prior to their arrival in your classroom/school?

4. Do you think you would have benefitted from some cultural training?

5. Have you searched for information on the Karen on your own?

6. Have you ever had contact with any of your Karen student's parents? If so, how often and in what capacity? Journal of Southeast Asian American Education \& Advancement, Vol. 10 (2015) 
Journal of Southeast Asian American Education and Advancement, Vol. 10 [2015], Iss. 1, Art. 2

\section{Gilhooly - Lessons Learned}

7. Have you ever visited any of your area family's homes?

8. What adjectives do you find yourself using when you describe your Karen students?

9. Do you think your Karen students are performing at grade level?

10. Do you find the addition of Karen students to your school and class a benefit or distraction?

11. Have you tried to incorporate any Karen related themes into your classes?

12. Have you acknowledged, in any way, to your classes the presence of Karen students? If so, how?

13. Do you feel the Karen are well integrated in your school?

14. Do you feel Karen students are integrated in your community?

15. Do you see the Karen students in your school being bullied? Please explain.

16. Have you ever retained a Karen student even though they did not meet grade requirements? 


\section{About the Author}

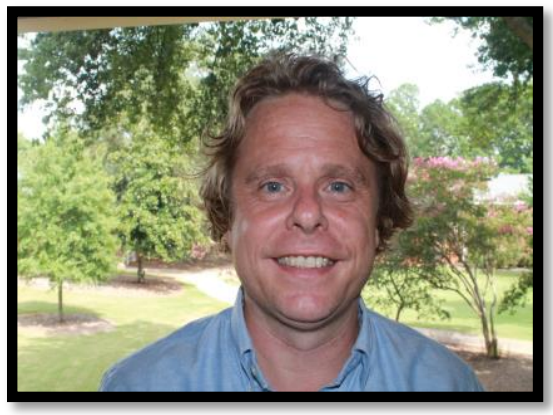

Daniel Gilhooly has taught ESL/EFL for over 17 years in the U.S. and South Korea. For the past four years he has worked extensively with Karen students as a collaborator, language tutor and mentor. He completed his Ph.D. from the University of Georgia's Language and Literacy Education Department in May 2014. 


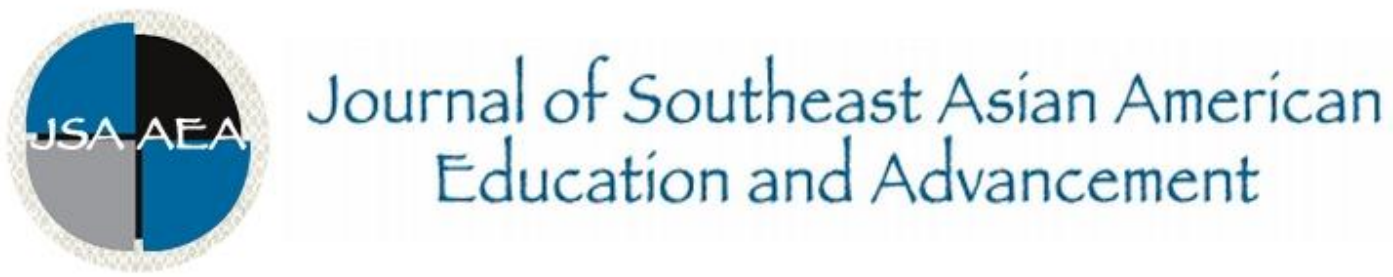

Volume 10 (2015)

WWW.JSAAEA.org

\section{Editor}

Dr. Wayne E. Wright

Purdue University

\section{Associate Editors}

Dr. Chhany Sak-Humphry

University of Hawaii at Manoa

Dr. Phitsamay Sychitkokhong Uy

University of Massachusetts, Lowell

\section{Book Review Editor}

Dr. Vichet Chhuon

University of Minnesota

\section{Creative Works Editor \\ Bryan Thao Worra \\ Lao Assistance Center}

\section{Journal Manager \\ Marshall Klassen \\ Purdue University}

\section{Editorial Review Board}

\author{
Dr. Steve Arounsack \\ California State University, Stanislaus \\ Sovicheth Boun \\ The State University of New York at Fredonia \\ Dr. George Chigas \\ University of Massachusetts, Lowell \\ Dr. Hien Duc Do \\ San Jose State University \\ Dr. Sophal Ear \\ U.S. Naval Postgraduate School \\ Dr. Jeremy Hein \\ University of Wisconsin, Eau Claire
}

\author{
Dr. Carl L. Bankston III \\ Tulane University \\ Dr. Phala Chea \\ Lowell Public Schools \\ Dr. Loan Dao \\ University of Massachusetts, Boston \\ Dr. Changming Duan \\ University of Missouri, Kansas City \\ Dr. Sothy Eng \\ Lehigh University \\ Dr. Vincent K. Her \\ University of Wisconsin, Eau Claire
}




\author{
Dr. Nancy H. Hornberger \\ University of Pennsylvania \\ Dr. Peter Nien-Chu Kiang \\ University of Massachusetts, Boston \\ Dr. Kevin K. Kumashiro \\ University of Illinois, Chicago \\ Dr. Ravy Lao \\ California State University, Los Angeles \\ Dr. Stacey Lee \\ University of Wisconsin, Madison \\ Dr. Sue Needham \\ California State University, Dominguez Hills \\ Dr. Max Niedzwiecki \\ Daylight Consulting Group \\ Dr. Clara Park \\ California State University, Northridge \\ Dr. Mark Pfeifer \\ SUNY Institute of Technology \\ Dr. Loan T. Phan \\ University of New Hampshire \\ Dr. Karen Quintiliani \\ California State University, Long Beach \\ Dr. Angela Reyes \\ Hunter College, The City University of New York \\ Dr. Fay Shin \\ California State University, Long Beach \\ Dr. Cathy J. Schlund-Vials \\ University of Connecticut, Storrs \\ Dr. Yer J. Thao \\ Portland State University \\ Dr. Myluong Tran \\ San Diego State University \\ Dr. Monica M. Trieu \\ Purdue University \\ Dr. Silvy Un \\ Frost Lake Elementary School \\ Dr. Terrence G. Wiley \\ Center for Applied Linguistics \\ Dr. Zha Blong Xiong \\ University of Minnesota
}

Dr. Samlong Inthaly Minneapolis Public Schools

Dr. Ketmani Kouanchao

Mt. San Jacinto College

Dr. Ha Lam

Arizona State University

Dr. Jonathan H. X. Lee

San Francisco State University

Dr. Monirith Ly

Royal University of Phnom Penh

Dr. Bic Ngo

University of Minnesota

Dr. Leakhena Nou

California State University, Long Beach

Dr. Isabelle Thuy Pelaud

San Francisco State University

Dr. Giang Pham

University of Massachusetts

Dr. Bounlieng Phommasouvanh

Minnesota Department of Education

Dr. Kalyani Rai

University of Wisconsin, Milwaukee

Dr. Soveacha Ros

Royal University of Phnom Penh

Dr. Nancy J. Smith-Hefner

Boston University

Dr. Christine Su

Ohio University

Dr. Loan Tran

University of California, Riverside

Dr. Tinou Tran

Alief Independent School District

Dr. Khatharya Um

University of California, Berkeley

Dr. Linda Trinh Vo

University of California, Irvine

Dr. Yang Sao Xiong

University of Wisconsin-Madison

Dr. Kou Yang

California State University, Stanislaus

\author{
Doctoral Student Editorial Review Board \\ Virak Chan \\ Keo Chea-Young \\ University of Pennsylvania \\ Peter Tan Keo \\ Columbia University
}

University of Texas at San Antonio

Annie BichLoan Duong

San Joaquin County Office of Education 


\author{
Minh Mai \\ University of Wisconsin-Madison \\ Hoa Nha Nguyen \\ Boston College \\ Malaphone Phommasa \\ University of California, Santa Barbara \\ Krissyvan Truong \\ Claremont Graduate University \\ Soua Xiong \\ San Diego State University \& Claremont \\ Graduate University
}

\author{
Dung Minh Mao \\ University of Minnesota
}

Thien-Huong Ninh

University of Southern California

Alisia Tran

University of Minnesota

Molly Wiebie

The University of Texas at Austin

Anna H. Yang

University of Georgia

\author{
Lesley Yang \\ University of Minnesota
}

